University of Nebraska - Lincoln

DigitalCommons@University of Nebraska - Lincoln

USGS Staff -- Published Research

US Geological Survey

2016

Using satellite vegetation and compound topographic indices to maphighly erodible cropland buffers for cellulosic biofuel cropdevelopments in eastern Nebraska, USA

Yingxin $\mathrm{Gu}$

ASRC Research \& Technology Solutions, yingxin.gu.ctr@usgs.gov

Bruce K. Wylie

USGSEROS, wylie@usgs.gov

Follow this and additional works at: http://digitalcommons.unl.edu/usgsstaffpub

Part of the Geology Commons, Oceanography and Atmospheric Sciences and Meteorology Commons, Other Earth Sciences Commons, and the Other Environmental Sciences Commons

$\mathrm{Gu}$, Yingxin and Wylie, Bruce K., "Using satellite vegetation and compound topographic indices to maphighly erodible cropland buffers for cellulosic biofuel cropdevelopments in eastern Nebraska, USA" (2016). USGS Staff -- Published Research. 903.

http:// digitalcommons.unl.edu/usgsstaffpub/903

This Article is brought to you for free and open access by the US Geological Survey at DigitalCommons@University of Nebraska - Lincoln. It has been accepted for inclusion in USGS Staff -- Published Research by an authorized administrator of DigitalCommons@University of Nebraska - Lincoln. 


\title{
Using satellite vegetation and compound topographic indices to map highly erodible cropland buffers for cellulosic biofuel crop developments in eastern Nebraska, USA
}

\author{
Yingxin $\mathrm{Gu}^{\mathrm{a}, *}$, Bruce K. Wylie ${ }^{\mathrm{b}}$ \\ a ASRC Research \& Technology Solutions, Contractor to U.S. Geological Survey (USGS) Earth Resources Observation and Science (EROS) Center, \\ 47914252 nd Street, Sioux Falls, SD 57198, USA \\ b USGS EROS, 47914 252nd Street, Sioux Falls, SD 57198, USA
}

\section{A R T I C L E I N F O}

\section{Article history:}

Received 30 October 2014

Received in revised form 15 June 2015

Accepted 16 June 2015

Available online 7 July 2015

\section{Keywords}

Cellulosic biofuel

Highly erodible cropland

Compound topographic index (CTI)

High topographic relief waterway buffer

Switchgrass biomass productivity

Land management

\begin{abstract}
A B S T R A C T
Cultivating annual row crops in high topographic relief waterway buffers has negative environmental effects and can be environmentally unsustainable. Growing perennial grasses such as switchgrass (Panicum virgatum L.) for biomass (e.g., cellulosic biofuel feedstocks) instead of annual row crops in these high relief waterway buffers can improve local environmental conditions (e.g., reduce soil erosion and improve water quality through lower use of fertilizers and pesticides) and ecosystem services (e.g., minimize drought and flood impacts on production; improve wildlife habitat, plant vigor, and nitrogen retention due to post-senescence harvest for cellulosic biofuels; and serve as carbon sinks). The main objectives of this study are to: (1) identify cropland areas with high topographic relief (high runoff potentials) and high switchgrass productivity potential in eastern Nebraska that may be suitable for growing switchgrass, and (2) estimate the total switchgrass production gain from the potential biofuel areas. Results indicate that about 140,000 hectares of waterway buffers in eastern Nebraska are suitable for switchgrass development and the total annual estimated switchgrass biomass production for these suitable areas is approximately 1.2 million metric tons. The resulting map delineates high topographic relief croplands and provides useful information to land managers and biofuel plant investors to make optimal land use decisions regarding biofuel crop development and ecosystem service optimization in eastern Nebraska.
\end{abstract}

(c) 2015 Elsevier Ltd. All rights reserved.

\section{Introduction}

Growing annual crops in riparian zones or waterway buffers with high topographic relief (i.e., steep slope areas) has numerous negative environmental consequences (e.g., soil erosion and water-quality effects of pesticide and fertilizer leakage) and can be environmentally unsustainable (Dosskey, 2001; Dosskey et al., 2002; Logan, 1990; Simpson et al., 2008; Spruill, 2000; http://water.epa.gov/lawsregs/guidance/cwa/305b/ upload/2009_01_22_305b_2004report_2004_305Breport.pdf). Several national conservation programs have provided incentives for converting agriculture lands to perennial grasses and trees within riparian zones (e.g., Conservation Reserve Program, Environmental

\footnotetext{
* Corresponding author. Tel.: +1 605594 6576; fax: +1 6055946529.

E-mail address: ygu@usgs.gov (Y. Gu).
}

Quality Incentives Program, Conservation Reserve Enhancement Program) to reduce negative environmental impacts, improve ecosystem services, and retain future sustainability in biomass production in these specific areas (Addy et al., 1999; Castelle et al., 1994; Lee et al., 2000; Piechnik et al., 2012; Sheridan et al., 1999; Tomer et al., 2003).

Previous studies indicate that cultivating perennial grass feedstocks such as switchgrass (Panicum virgatum L.) and prairie cordgrass (Spartina pectinata) for biofuel is more economically and environmentally sustainable than using corn (Zea maize L.) for producing ethanol (Bracmort, 2010; Bracmort et al., 2010; Bransby et al., 1998; Guretzky et al., 2011; Monti et al., 2012; Perrin et al., 2008; Sanderson et al., 2006, 1996; Schmer et al., 2010, 2008; Vadas et al., 2008). Corn-based ethanol development has been associated with global food shortages, livestock and food price increases, soil erosion, greater demands for irrigation water, and water-quality impairment (Buyx and Tait, 2011; Gelfand et al., 
2010; Pimentel, 2009; Schnepf and Yacobucci, 2010; Searchinger et al., 2008; Trostle, 2008). As a result of dramatically increasing demand for biofuel products (Perlack et al., 2005; http://www. usda.gov/documents/USDA_Biofuels_Report_6232010.pdf; http:// www.gpo.gov/fdsys/pkg/BILLS-110hr6enr/pdf/BILLS-110hr6enr. pdf) and future environmental sustainability, the development of perennial grass feedstocks for biofuel production is likely to increase in the near future (Bracmort, 2010; Bracmort et al., 2010; Schnepf and Yacobucci, 2010). Commercial production of switchgrass for bioenergy will be undertaken on a large scale when bioenergy infrastructures and refineries (biomass supply chains, centralization of fuel supplies) are well developed (Mitchell et al., 2012).

Growing perennial grasses such as switchgrass and prairie cordgrass for biofuel in riparian zones, stream waterway buffers, and highly erodible cropland areas has been proposed and investigated (Dominguez-Faus et al., 2009; Mersie et al., 2006; Powers et al., 2010; Sanderson, 2008; Sanderson et al., 2001; Tufekcioglu et al., 2003; Koh et al., 2009; http://nac.unl.edu/buffers/guidelines/4_ opportunities/6.html; http://www.globalbioenergy.org/uploads/ media/0702_FAO_-Water_quality_and_environmental_dimensions_ in_biofuel_production.pdf; https://bioenergy.ornl.gov/papers/ misc/switgrs.html). Cultivating perennial grass in these high reliefs, intensive agriculture areas can improve local environment conditions and ecosystem services (Dominguez-Faus et al., 2009; Powers et al., 2010; Sanderson et al., 2001; Tufekcioglu et al., 2003). However, thus far, investigations are only at the planning stages or are limited to a few experimental field sites. To date, we are not aware of previous studies that identify and map high topographic relief, marginally productive croplands (where grass waterways would be highly beneficial) over large regions that may be considered for cellulosic biofuel development.

In this study, we used 30-m hydrological data (i.e., U.S. Geological Survey Compound Topographic Index) to map waterway buffers in high topographic relief croplands. Our main objectives were to: (1) identify cropland with steep slopes, high erosion potential, and high switchgrass productivity potential in eastern Nebraska that are potentially suitable to convert to cellulosic biofuel crops, and (2) estimate the total production gain from switchgrass in the high erosion croplands with conversion potential. Results from this study will help land managers and biofuel plant investors make optimal land use decisions regarding sustainable biofuel crop development to optimize ecosystem services in eastern Nebraska.

\section{Materials and methods}

\subsection{Study area}

Eastern Nebraska (Fig. 1) was selected as a pilot study area for demonstration and illustration purposes. The main land cover types in the study area are cultivated crops (approximately 64\%) and grassland (approximately 28\%) (Homer et al., 2004). Crops and grasslands are highly productive in this study area because of the humid continental climate. Annual precipitation ranges from 600 to $900 \mathrm{~mm}$ and generally increases from west to east in the study area.

\subsection{USGS Compound Topographic Index (CTI) map}

The CTI is a commonly used hydrological measure of a site and may be interpreted as the steady-state wetness of an area (i.e., areas with probable run-on moisture). CTI is a function of both the slope and the upstream contributing area and can be calculated from a DEM (Digital Elevation Model) (http://geology.er.usgs.gov/ eespteam/terrainmodeling/dem_derived_maps.htm). Pixels with high CTI values (i.e., >12) usually represent water catchment areas (wetlands, lakes, streams and rivers). The $30-\mathrm{m}$ spatial resolution CTI map developed by the USGS Elevation Derivatives for National Applications (EDNA) program (http://edna.usgs.gov/ Edna/datalayers/cti.asp) was used in this study (Fig. 2a and b).

\subsection{Crop mask and switchgrass productivity estimation maps}

A 10-year series (2000-2009) of yearly crop type maps for eastern Nebraska (250-m resolution) (Howard et al., 2012) was used to develop a crop mask for the study area. A crop pixel was assigned when 5 or more years were in crops. In addition, a 3year (2008-2010) averaged switchgrass productivity potential (i.e., predicted growing season averaged Normalized Difference Vegetation Index (GSN)) map developed by Gu et al. (2015) for eastern Nebraska was used to identify the highly productive switchgrass $(G S N \geq 0.5)$ regions. Fig. $2 c$ and $d$ show the crop mask and the

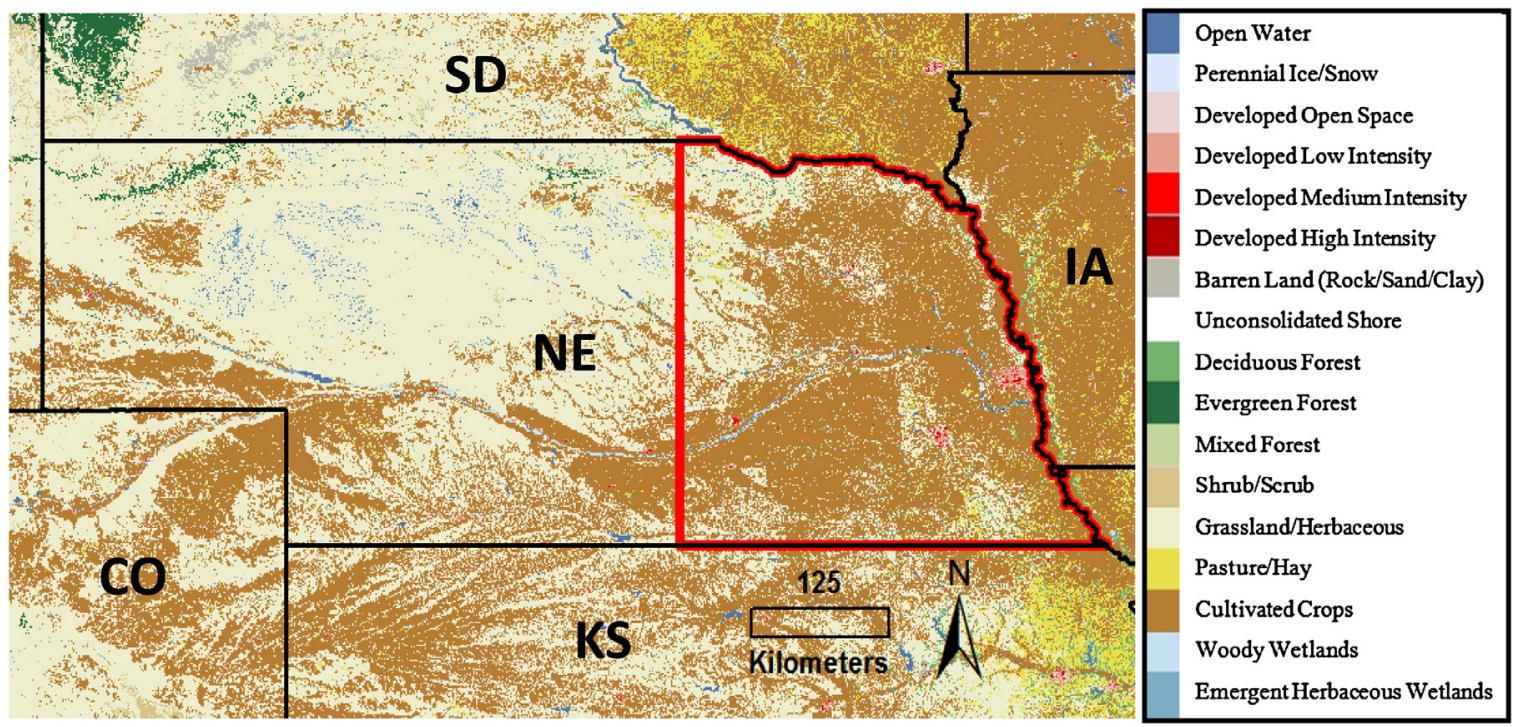

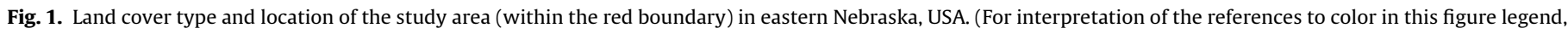
the reader is referred to the web version of this article.) 

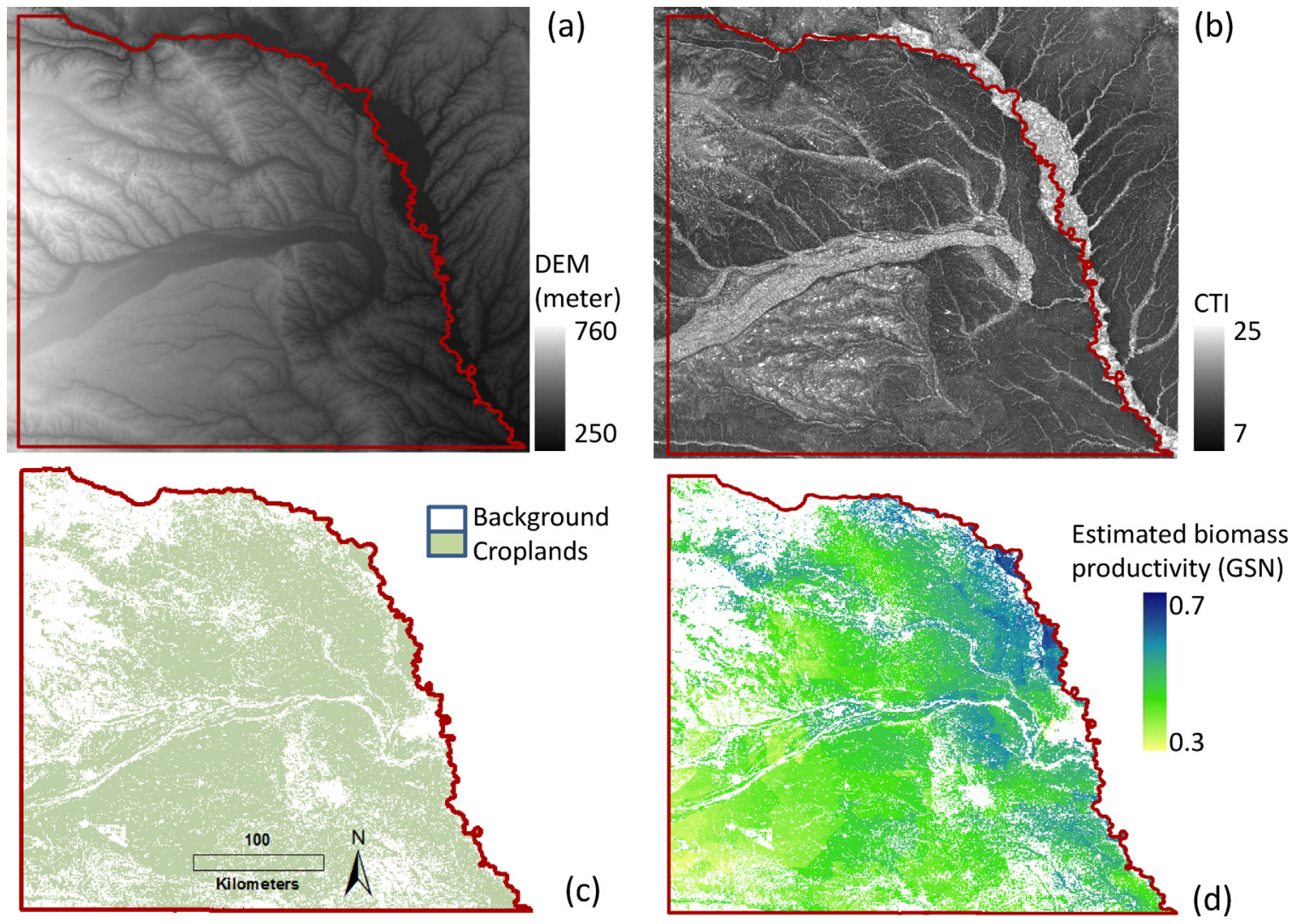

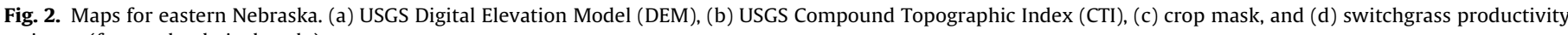
estimate (for cropland pixels only).

estimated switchgrass productivity (for crop pixels only) in eastern Nebraska.

\subsection{Identification of high topographic relief marginally productive croplands in eastern Nebraska}

Fig. 3 is a flowchart summarizing our approach to identify marginally productive croplands with high topographic relief (i.e., highly erodible sites) and high switchgrass productivity potential that are suitable for development as perennial grass buffers. The procedure consisted of the following steps:

1. Calculate the mean $\mathrm{CTI}$ value ( $\mathrm{CTI}$ mean $)$ within a $5 \times 5$ pixel (i.e., $150 \times 150 \mathrm{~m}$ ) window for each pixel.

2. Establish the criteria for the high topographic relief waterway buffer classification, which excludes water bodies (e.g., lakes) and extremely high CTI regions, based on the CTI map: $\mathrm{CTI}>(1.2 \times \mathrm{CTI}$ mean $)$ and $12<\mathrm{CTI}<20$. In extremely high CTI regions, riparian trees are a preferred cover type for reducing runoff and withstanding high magnitude flooding.

3. Classify each pixel as either a waterway or non-waterway buffer using the criteria from step 2.

4. Remove pixels from the identified waterway buffers if they are (1) non-crop pixels based on the crop mask or (2) unproductive switchgrass pixels (i.e., GSN $<0.5$ ) based on the switchgrass productivity map.

5. Exclude small isolated waterway buffers (i.e., $<5$ hectares within a 100-hectare-square region) from the identified biofuel potential areas based on economic considerations; the biofuel potential areas should be large enough (i.e., $\geq 5$ hectares) to facilitate efficient harvest and maintenance, as well as control transportation costs.

\subsection{Estimation of switchgrass biomass productivity for biofuel potential areas}

In order to assess the feasibility and evaluate the future sustainability of converting the identified marginally productive cropland to switchgrass, we estimated the total expected switchgrass biomass productivity in the identified biofuel waterway potential areas. An empirical equation developed by Gu et al. (2013, Eq. (1)) for calculating grassland biomass productivity based on the GSN was used to estimate the grassland productivity.

Biomass productivity $\left(\mathrm{kg} \mathrm{ha}^{-1} \mathrm{yr}^{-1}\right)=9936.5 \times \mathrm{GSN}-1554$

Because switchgrass is highly productive (and more productive when fertilizers and chemicals are applied to encourage its growth as a dense monoculture) and has higher biomass production than most grassland species, the total estimated switchgrass biomass productivity was assumed to be double that of the total estimated grassland biomass productivity based on previous study results (Anderson-Teixeira et al., 2012; Behrman et al., 2012; Bonin and Lal, 2014; Fike et al., 2006; Jager et al., 2010; Kiniry et al., 2008; McLaughlin et al., 2006; Schmer et al., 2010; Tulbure et al., 2012; Vogel et al., 2002; Wullschleger et al., 2010).

\section{Results and discussion}

\subsection{Map of potential biofuel feedstock areas in eastern Nebraska}

It is difficult to illustrate the identified biofuel feedstock potential areas (waterway buffers) for the entire study area because of the large spatial extent of the study area. For visualization purposes, two small subsets from the study area were selected to generate zoomed in maps (Fig. 4 zoom regions 1 and 2). 


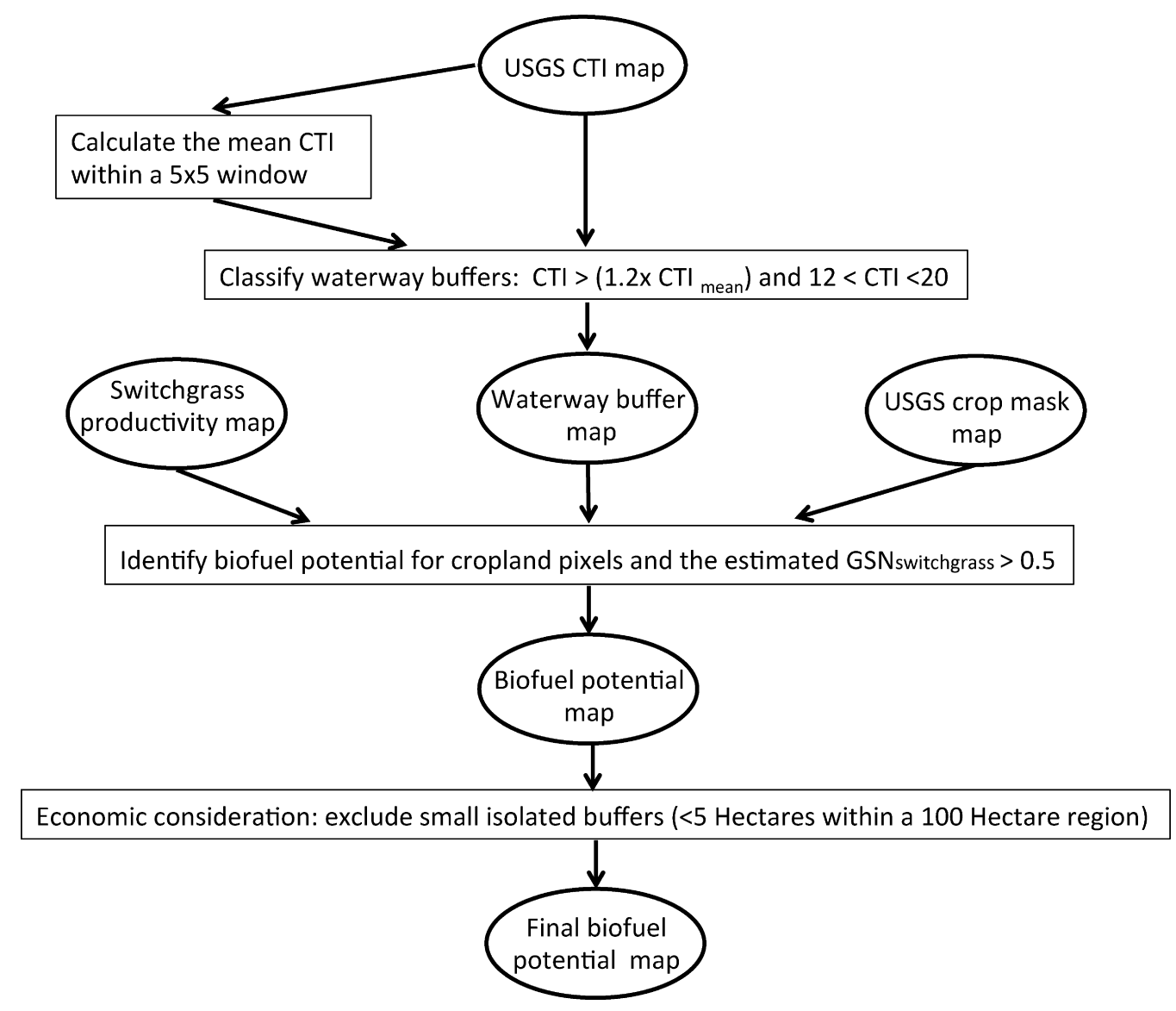

Fig. 3. Flowchart for identifying biofuel waterway buffers.

The main vegetation cover types for zoom region 1 are grassland and cropland; loamy and sandy soils are dominant in this region (http://www.nrcs.usda.gov/Internet/FSE_DOCUMENTS/ nrcs142p2_028388.pdf). Zoom region 2 is dominated by croplands; productivity in this region is relatively high because of the favorable climate and soil conditions.

The zoomed maps for the two selected regions in Fig. 4 include (4a) CTI maps, (4b) high topographic relief waterway buffers (red) overlaid on the CTI maps, and (4c) the final biofuel potential areas (green) overlaid on the CTI maps. Water bodies and extremely high moisture areas, which are not suitable for switchgrass development, were excluded from the identified waterway buffers (zoomed maps 4b). Moreover, non-cropland pixels, unproductive switchgrass pixels (i.e., GSN <0.5), and the isolated waterway buffer pixels were also excluded from the identified biofuel potential region (zoomed maps 4c). Overall, the eastern part of the study area (highly productive region) has more biofuel potential areas than the northwestern part of the study area (less productive, due to drier climate and sandy soil).

\subsection{The estimated switchgrass biomass productivity for the biofuel potential areas in eastern Nebraska}

Approximately 140,000 hectares $\left(1400 \mathrm{~km}^{2}\right)$ of highly erodible cropland buffers in eastern Nebraska were identified as suitable regions for switchgrass production. However, a portion of this region is underlain by the Sand Hills ecoregion, which is characterized by sand dune systems, sandy soil, native grassland, and semiarid climate conditions (http://www.worldwildlife.org/ ecoregions/na0809). As a result, we excluded areas located within the Sand Hills ecoregion (Fig. 4, approximately 4000 hectares) from the biofuel potential areas to avoid sand dune activation. The final total estimated switchgrass biomass productivity gain from the biofuel potential areas is approximately 1.2 million metric tons.

\subsection{Discussion}

In zoom region 1, a large proportion of the identified high relief waterway buffers (Fig. 4 zoom 1b, red) were excluded from the final biofuel potential areas (Fig. 4 zoom 1c, green). These areas were excluded mainly because of the large proportion of non-cropland pixels identified in this region, which indicate that land managers were already aware of water erosion impacts in this high relief region or found problems with cropping in these areas (two potential explanations based on the observed trend). On the other hand, for zoom region 2 , only a small proportion of the identified high relief waterway buffers (Fig. 4 zoom 2b, red) were excluded from the final biofuel potential areas (Fig. 4 zoom 2c, green). Domination by cropland, along with favorable environmental conditions for switchgrass production, resulted in a large proportion of the high relief waterway buffers in this region being suitable for switchgrass development.

As mentioned in the Introduction section, cultivating perennial grasses (e.g., switchgrass) in high relief intensive agriculture areas can provide both economic and ecosystem service returns. Advantages of converting agricultural lands to perennial grass biofuel feedstocks in the riparian buffers and high topographic relief areas include: (1) filtering of surface-water flows, reducing export of cropland nitrogen, and improving water quality because switchgrass requires less fertilizer and pesticides (Bransby et al., 1998; Liebig, 2006; Sladden et al., 1991); (2) reducing runoff, reducing soil erosion, and stabilizing stream banks as a result of 

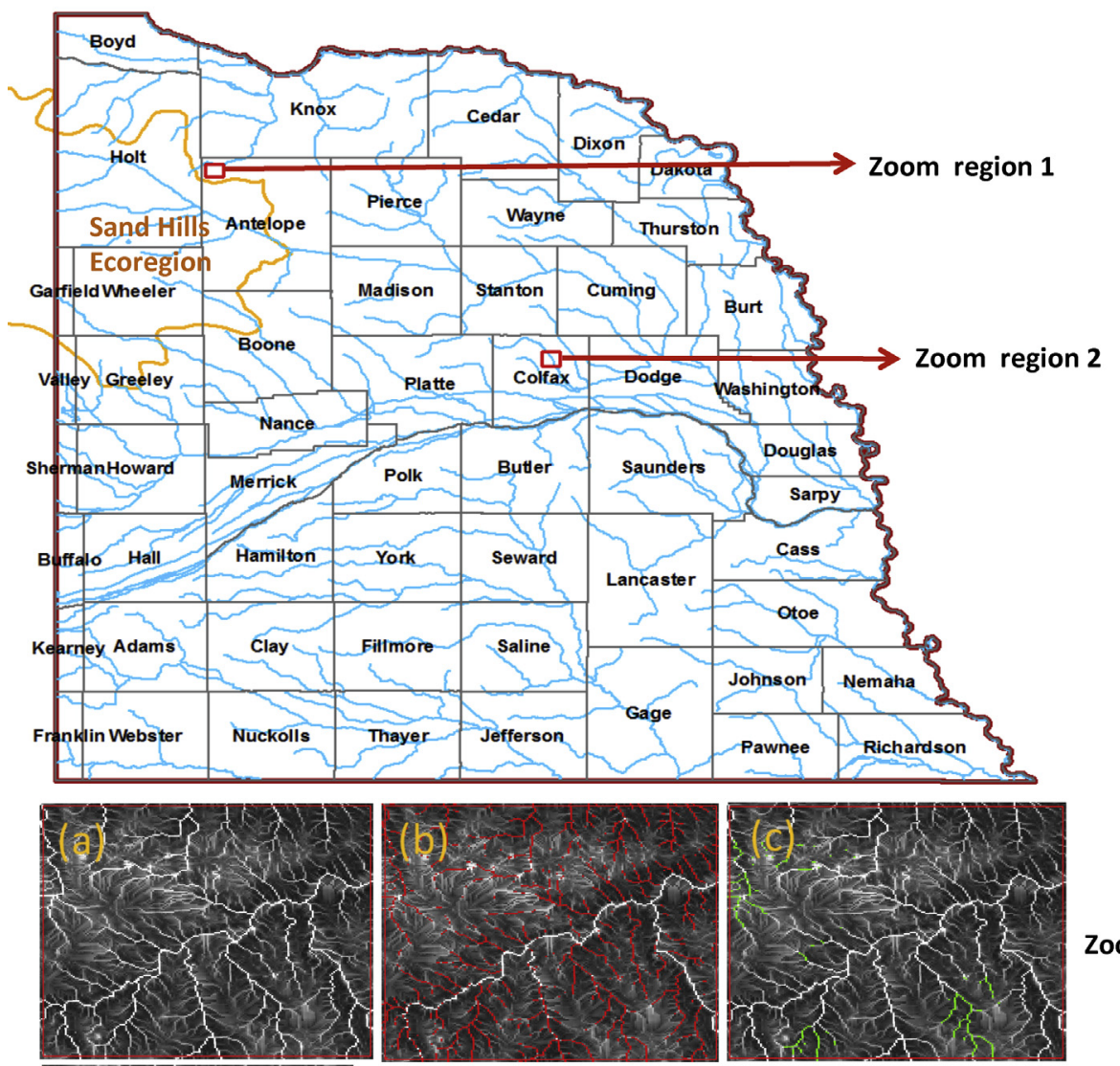

Zoom region 1
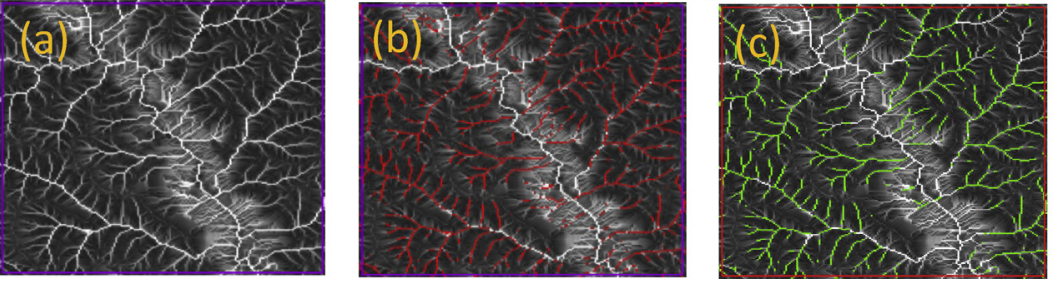

Zoom region 2

Fig. 4. Study area showing county names and county boundaries (gray), streams and rivers (cyan), the Sand Hills ecoregion (orange), and the two zoomed boxes (red). Zoom region 1 is located outside the eastern edge of the Sand Hills ecoregion (northwestern Antelope County, Nebraska). Zoom region 2 is located within Colfax County, Nebraska. (a) Original CTI map, (b) high topographic relief waterway buffers (red) overlaid on the CTI map, and (c) final biofuel potential areas (green) overlaid on the CTI map. (For interpretation of the references to color in this figure legend, the reader is referred to the web version of this article.)

increased surface roughness from vegetation structure and the well-developed rhizome and root systems of switchgrass (Gyssels and Poesen, 2003); (3) decreasing drought and flood impacts on production since perennial grass feedstocks, especially cordgrass, are tolerant to drought, flood, and salinity (Kim et al., 2010); (4) increasing economic returns due to reduced usage of irrigation water; (5) improving wildlife habit (e.g., providing cover during critical nesting periods for grassland birds) (Murray et al., 2003; Robertson et al., 2012; Schaap, 2011; http://www.michigandnr. com/publications/pdfs/huntingwildlifehabitat/landowners_guide/ species_mgmt/pheasants.htm) and plant vigor (i.e., carbohydrate reserves), and retaining nitrogen because of late, post-senescence harvest for cellulosic biofuels (Garland, 2010); (6) improving carbon sequestration and carbon retention (i.e., carbon sinks) (Bransby et al., 1998; Frank et al., 2004; Ma et al., 2000; Zeri et al., 2011); and (7) reducing dependency on foreign oil.

Intensively harvesting crop residues (e.g., corn stover from row crop fields) for biofuel or livestock is considered environmentally unsustainable, because it can deplete soil carbon stocks, reduce soil fertility, and advance erosion (Follett, 2001; Wilhelm et al., 2010, 2007; https://www.iowacorn.org/documents/filelibrary/
research/research_reports/IowaCornResearchBrochure_FINAL 31478BB786257.pdf). Converting these high relief waterway buffers to grazing lands may be a viable option. However, heavy grazing in these riparian areas would decrease vegetation cover, lead to channel incisions and a lower water table, and result in sediment delivery above normal regimes (Kamp et al., 2013). Moreover, fencing these waterway buffers from grazing would be expensive. Growing hay in waterway buffers would be another alternative choice, but cutting hay in the peak crude protein content period would impact the nutrient retention and plant vigor (resulting in a loss of substantial carbohydrate stocks) (Watts, 2009).

\section{Summary}

This study mapped marginal croplands with steep slopes that are potentially productive sites for growing switchgrass as a biomass feedstock in eastern Nebraska, USA. The total estimated biomass production "gain" from switchgrass is approximately 1.2 million metric tons for the biofuel potential areas (approximately 140,000 hectares). Results from this study provide preliminary 
information to land managers and biofuel plant investors regarding sustainable biofuel crop development in eastern Nebraska.

In future studies, we plan to investigate how economic considerations influence suitable site selection (e.g., identifying existing roads and railways for biomass transportation and centralization; assessing the nearest starch-based ethanol production plants that could be modified for cellulosic ethanol production). We also plan to validate the results derived from this study using ground observations, and extend this method to other geographic regions in the United States or other countries around the world.

\section{Acknowledgements}

This work was performed under USGS contract G13PC00028 and funded by the USGS Land Change Science Program in support of Renewable Energy-Biofuels. The authors thank Sandra Poppenga and Bruce Worstell for providing the USGS 30-m high resolution CTI data. The authors thank Daniel M. Howard for providing yearly crop mask maps for Nebraska. The authors also thank Norman B. Bliss, Thomas Adamson, Sandra C. Cooper, and two anonymous reviewers for their valuable suggestions and comments. Any use of trade, product, or firm names is for descriptive purposes only and does not imply endorsement by the U.S. Government.

\section{References}

Addy, K., Gold, A., Groffman, P., Jacinthe, P., 1999. Ground water nitrate removal in subsoil of forested and mowed riparian buffer zones. J. Environ. Qual. 28, 962-970.

Anderson-Teixeira, K.J., Duval, B.D., Long, S.P., DeLucia, E.H., 2012. Biofuels on the landscape: is "land sharing" preferable to "land sparing"? Ecol. Appl. 22, 2035-2048.

Behrman, K.D., Kiniry, J.R., Winchell, M., Juenger, T.E., Keitt, T.H., 2012. Spatial forecasting of switchgrass productivity under current and future climate change scenarios. Ecol. Appl. 23, 73-85.

Bonin, C.L., Lal, R., 2014. Aboveground productivity and soil carbon storage of biofuel crops in Ohio. GCB Bioenergy 6 (1), 67-75.

Bracmort, K., 2010. Meeting the Renewable Fuel Standard (RFS) Mandate for Cellulosic Biofuels: Questions and Answers. In: Cong. Research Serv. Report for Congress, RL41106.

Bracmort, K., Schnepf, R., Stubbs, M., Yacobucci, B.D., 2010. Cellulosic Biofuels: Analysis of Policy Issues for Congress. In: Cong. Research Serv. Report for Congress, RL34738.

Bransby, D.I., McLaughlin, S.B., Parrish, D.J., 1998. A review of carbon and nitrogen balances in switchgrass grown for energy. Biomass Bioenergy 14, 379-384.

Buyx, A., Tait, J., 2011. Ethical framework for biofuels. Science 332, 540-541.

Castelle, A.J., Johnson, A., Conolly, C., 1994. Wetland and stream buffer size requirements - a review. J. Environ. Qual. 23, 878-882.

Dominguez-Faus, R., Powers, S.E., Burken, J.G., Alvarez, P.J., 2009. The water footprint of biofuels: a drink or drive issue? Environ. Sci. Technol. 43, 3005-3010.

Dosskey, M.G., 2001. Toward quantifying water pollution abatement in response to installing buffers on crop land. Environ. Manage. 28, 577-598.

Dosskey, M.G., Helmers, M.J., Eisenhauer, D.E., Franti, T.G., Hoagland, K.D., 2002. Assessment of concentrated flow through riparian buffers. J. Soil Water Conserv. 57, 336-343.

Fike, J.H., Parrish, D.J., Wolf, D.D., Balasko, J.A., Green Jr., J.T., Rasnake, M., Reynolds, J.H., 2006. Long-term yield potential of switchgrass-for-biofuel systems. Biomass Bioenergy 30, 198-206.

Follett, R., 2001. Soil management concepts and carbon sequestration in cropland soils. Soil Tillage Res. 61, 77-92.

Frank, A.B., Berdahl, J.D., Hanson, J.D., Liebig, M.A., Johnson, H.A., 2004. Biomass and carbon partitioning in switchgrass. Crop Sci. 44, 1391-1396.

Garland, C.D., 2010. Growing and Harvesting Switchgrass for Ethanol Production in Tennessee. Tennessee Biofuels Initiative. In: University of Tennessee Institute of Agriculture SP701A-5M-5/08 (Rep) R12-4110-070-019-08 08-0120.

Gelfand, I., Snapp, S.S., Robertson, G.P., 2010. Energy efficiency of conventional, organic, and alternative cropping systems for food and fuel at a site in the U.S. Midwest. Environ. Sci. Technol. 44, 4006-4011.

Gu, Y., Wylie, B.K., Howard, D.M., 2015. Estimating switchgrass productivity in the Great Plains using satellite vegetation index and site environmental variables. Ecol. Indic. 48, 472-476.

Gu, Y., Wylie, B.K., Bliss, N.B., 2013. Mapping grassland productivity with 250-m eMODIS NDVI and SSURGO database over the Greater Platte River Basin, USA. Ecol. Indic. 24, 31-36.

Guretzky, J.A., Biermacher, J.T., Cook, B.J., Kering, M.K., Mosali, J., 2011. Switchgrass for forage and bioenergy: harvest and nitrogen rate effects on biomass yields and nutrient composition. Plant Soil 339, 69-81.
Gyssels, G., Poesen, J., 2003. The importance of plant root characteristics in controlling concentrated flow erosion rates. Earth Surf. Proc. Land. 28 371-384.

Homer, C., Huang, C., Yang, L., Wylie, B., Coan, M., 2004. Development of a 2001 national land-cover database for the United States. Photogramm. Eng. Remote Sens. 70, 829-840

Howard, D.M., Wylie, B.K., Tieszen, L.L., 2012. Crop classification modelling using remote sensing and environmental data in the Greater Platte River basin, USA Int. J. Remote Sens. 33, 6094-6108.

Jager, H.I., Baskaran, L.M., Brandt, C.C., Davis, E.B., Gunderson, C.A., Wullschleger, S.D., 2010. Empirical geographic modeling of switchgrass yields in the United States. GCB Bioenergy 2, 248-257.

Kamp, K.V., Rigge, M., Troelstrup Jr., N.H., Smart, A.J., Wylie, B., 2013. Detecting channel riparian vegetation response to best-management-practices implementation in ephemeral streams with the use of spot high-resolution visible imagery. Rangel. Ecol. Manage. 66, 63-70.

Kim, S., Rayburn, A.L., Lee, D.K., 2010. Genome size and chromosome analyses in prairie cordgrass. Crop Sci. 50, 2277-2282.

Kiniry, J.R., Schmer, M.R., Vogel, K.P., Mitchell, R.B., 2008. Switchgrass biomass simulation at diverse sites in the northern great plains of the U.S. Bioenergy Res. 1, 259-264.

Koh, L.P., Levang, P., Ghazoul, J., 2009. Designer landscapes for sustainable biofuels. Trends Ecol. Evol. 24, 431-438.

Lee, K.-H., Isenhart, T.M., Schultz, R.C., Mickelson, S.K., 2000. Multispecies riparian buffers trap sediment and nutrients during rainfall simulations. J. Environ. Qual. $29,1200-1205$

Liebig, M.A., 2006. USDA and DOE favor switchgrass for biomass fuel. Ind. Bioprocess. 28,7

Logan, T.J., 1990. Agricultural best management practices and groundwater protection. J. Soil Water Conserv. 45, 201-206.

Ma, Z., Wood, C.W., Bransby, D.I., 2000. Carbon dynamics subsequent to establishment of switchgrass. Biomass Bioenergy 18, 93-104.

McLaughlin, S.B., Kiniry, J.R., Taliaferro, C.M., De La Torre Ugarte, D., 2006. Projecting yield and utilization potential of switchgrass as an energy crop. Adv. Agron. 90 267-297.

Mersie, W., Seybold, C., Wu, J., McNamee, C., 2006. Atrazine and metolachlor sorption to switchgrass residues. Commun. Soil Sci. Plan. 37, 465-472.

Mitchell, R., Vogel, K.P., Uden, D.R., 2012. The feasibility of switchgrass for biofuel production. Biofuels 3, 47-59.

Monti, A., Barbanti, L., Zatta, A., Zegada-Lizarazu, W., 2012. The contribution of switchgrass in reducing GHG emissions. GCB Bioenergy 4, 420-434.

Murray, L.D., Best, L.B., Jacobsen, T.J., Braster, M.L., 2003. Potential effects on grassland birds of converting marginal cropland to switchgrass biomass production. Biomass Bioenergy 25, 167-175.

Perlack, R.D., Wright, L.L., Turhollow, A.F., Graham, R.L., Stokes, B.J., Erbach, D.C., 2005. Biomass as Feedstock for a Bioenergy and Bioproducts Industry: The Technical Feasibility of a Billion-ton Annual Supply. Oak Ridge National Laboratory, TN

Perrin, R., Vogel, K., Schmer, M., Mitchell, R., 2008. Farm-scale production cost of switchgrass for biomass. Bioenergy Res. 1, 91-97.

Piechnik, D., Goslee, S., Veith, T., Bishop, J., Brooks, R., 2012. Topographic placement of management practices in riparian zones to reduce water quality impacts from pastures. Landsc. Ecol. 27, 1307-1319.

Pimentel, D., 2009. Corn and cellulosic ethanol problems and soil erosion. In: Rattan Lal, Stewart, B.A. (Eds.), Soil Quality and Biofuel Production. CRC Press, Print ISBN: 978-1-4398-0073-7, eBook ISBN: 978-0-415-99830-7.

Powers, S.E., Dominguez-Faus, R., Alvarez, P.J.J., 2010. Opinion: the water footprint of biofuel production in the USA. Biofuels 1, 255-260.

Robertson, B.A., Rice, R.A., Sillett, T.S., Ribic, C.A., Babcock, B.A., Landis, D.A., Herkert, J.R., Fletcher, R.J., Fontaine, J.J., Doran, P.J., Schemske, D.W., 2012. Are agrofuels a conservation threat or opportunity for grassland birds in the United States? Condor 114, 679-688.

Sanderson, M.A., 2008. Upland switchgrass yield, nutritive value, and soil carbon changes under grazing and clipping. Agron. J. 100, 510-516.

Sanderson, M.A., Adler, P.R., Boateng, A.A., Casler, M.D., Sarath, G., 2006. Switchgrass as a biofuels feedstock in the USA. Can. J. Plant Sci. 86, 1315-1325.

Sanderson, M.A., Jones, R.M., McFarland, M.J., Stroup, J., Reed, R.L., Muir, J.P., 2001. Nutrient movement and removal in a switchgrass biomass-filter strip system treated with dairy manure. J. Environ. Qual. 30, 210-216.

Sanderson, M.A., Reed, R.L., McLaughlin, S.B., Wullschleger, S.D., Conger, B.V., Parrish, D.J., Wolf, D.D., Taliaferro, C., Hopkins, A.A., Ocumpaugh, W.R., Hussey, M.A., Read, J.C., Tischler, C.R., 1996. Switchgrass as a sustainable bioenergy crop. Bioresour. Technol. 56, 83-93.

Schaap, H., 2011. Ring-necked pheasant. Pro Rege 40, 15

Schmer, M.R., Mitchell, R.B., Vogel, K.P., Schacht, W.H., Marx, D.B., 2010. Spatial and temporal effects on switchgrass stands and yield in the Great Plains. Bioenergy Res. 3, 159-171.

Schmer, M.R., Vogel, K.P., Mitchell, R.B., Perrin, R.K., 2008. Net energy of cellulosic ethanol from switchgrass. Proc. Natl. Acad. Sci. U. S. A. 105 464-469.

Schnepf, R., Yacobucci, B.D., 2010. Selected Issues Related to an Expansion of the Renewable Fuel Standard (RFS). In: Cong. Research Serv. Report for Congress, R40155.

Searchinger, T., Heimlich, R., Houghton, R.A., Dong, F., Elobeid, A., Fabiosa, J., Tokgoz, S., Hayes, D., Yu, T.-H., 2008. Use of U.S. croplands for biofuels increases 
greenhouse gases through emissions from land-use change. Science 319, $1238-1240$.

Sheridan, J., Lowrance, R., Bosch, D., 1999. Management effects on runoff and sediment transport in riparian forest buffers. Trans. ASAE (Am. Soc. Agric. Eng.) 42, 55-64

Simpson, T.W., Sharpley, A.N., Howarth, R.W., Paerl, H.W., Mankin, K.R., 2008. The new gold rush: fueling ethanol production while protecting water quality. J. Environ. Qual. 37, 318-324.

Sladden, S.E., Bransby, D.I., Aiken, G.E., 1991. Biomass yield, composition and production costs for eight switchgrass varieties in Alabama. Biomass Bioenergy 1 , $119-122$.

Spruill, T.B., 2000. Statistical evaluation of effects of riparian buffers on nitrate and ground water quality. J. Environ. Qual. 29, 1523-1538.

Tomer, M.D., James, D.E., Isenhart, T.M., 2003. Optimizing the placement of riparian practices in a watershed using terrain analysis. J. Soil Water Conserv. 58, 198-206.

Trostle, R., 2008. Global Agricultural Supply and Demand: Factors Contributing to the Recent Increase in Food Commodity Prices. Economic Research Service, WRS0801. US Department of Agriculture, Washington.

Tufekcioglu, A., Raich, J., Isenhart, T., Schultz, R., 2003. Biomass, carbon and nitrogen dynamics of multi-species riparian buffers within an agricultural watershed in Iowa, USA. Agrofor. Syst. 57, 187-198.
Tulbure, M.G., Wimberly, M.C., Boe, A., Owens, V.N., 2012. Climatic and genetic controls of yields of switchgrass, a model bioenergy species. Agric. Ecosyst. Environ. 146, 121-129.

Vadas, P.A., Barnett, K.H., Undersander, D.J., 2008. Economics and energy of ethano production from alfalfa, corn, and switchgrass in the Upper Midwest, USA. Bioenergy Res. 1, 44-55.

Vogel, K.P., Brejda, J.J., Walters, D.T., Buxton, D.R., 2002. Switchgrass biomass production in the Midwest USA. Agron. J. 94, 413-420.

Watts, K.A., 2009. Carbohydrates in forage: what is a safe grass. Adv. Equine Nutr IV

Wilhelm, W.W., Hess, J.R., Karlen, D.L., Johnson, J.M., Muth, D.J., Baker, J.M., Gollany, H.T., Novak, J.M., Stott, D.E., Varvel, G.E., 2010. Review: balancing limiting factors \& economic drivers for sustainable Midwestern US agricultural residue feedstock supplies. Ind. Biotechnol. 6, 271-287.

Wilhelm, W.W., Johnson, J.M., Karlen, D.L., Lightle, D.T., 2007. Corn stover to sustain soil organic carbon further constrains biomass supply. Agron. J. 99, 1665-1667.

Wullschleger, S.D., Davis, E.B., Borsuk, M.E., Gunderson, C.A., Lynd, L.R., 2010 Biomass production in switchgrass across the United States: database description and determinants of yield. Agron. J. 102, 1158-1168.

Zeri, M., Anderson-Teixeira, K., Hickman, G., Masters, M., DeLucia, E., Bernacchi, C.J., 2011. Carbon exchange by establishing biofuel crops in Central Illinois. Agric. Ecosyst. Environ. 144, 319-329. 